\title{
AYURLOG
}

National Journal of Research in Ayurved Science

http://www.ayurlog.com

Nov- 2020 | Volume $08^{\text {th }} \mid$ Issue: $6^{\text {th }}$

ISSN: 2320-7329

\section{Effect of uttarbasti locally in fallopian tubal block - a case study}

\section{Mule Kavita C. ${ }^{1}$, Deshmukh Jayashri $\mathbf{S}^{2}$}

1. Ph. D. (Scholar), Associate Professor, Department of PrasutiTantra and Stree Rog, Yashwant Ayurveda College, Kodoli, Dist-Kolhapur, Maharashtra, India

2. HOD and Professor \& Ph. D. Guide, Prasuti Tantra \& Strirog CSMSS's Ayurved Mahavidyalaya Aurangabad, Maharashtra, India, jayashrisdeshmukh@gmail.com

*Corresponding author: E-mail-kvt126@gmail.com

ABSTRACT: The present Case study was carried out to evaluate the role of Uttar Basti in tubal blockage, in order to establish it as a safer and cost-effective Ayurvedic treatment modality. The criteria for selection of patient tubal blockage diagnosed in hysterosalpingography

(HSG). Uttar

Basti was administered, after cessation of menstruation, to the screened patient, through hematological, urinary, and serological (HIV, VDRL, HBsAg) investigations. The results suggest that Uttar Basti is a highly significant treatment modality for tubal blockage in this Patient, with no apparent complications.

Uttarbasti is ideal local therapy is to be adopted in tubal block. Kshartail is very good vata kaphashamak guna and lekhan properties, taila is having the property to reach minute channels in body. Phalaghruta is best for all yonirogas, also to reduces dhaha which is due to Kshar tail.
Keywords: Tubal block, Uttarbasti, Kshartail, Phalagruta.

\section{INTRODUCTION:}

Artavavaha Srotas covers the whole female reproductive tract and encompasses it as a structural and functional unit from the hypothalamus to the uterus. It represents not only the hormones related to reproduction at the physiological level, but also covers all the structures related to female reproductive organs at the anatomical level. Fallopian tubes are very important structures of the Artavavaha Srotas, as they carry Bija Rupi Artava. Thus, fallopian tubes can be termed as Bija Vaha Srotas. Infertility is define as failure to conceive within one or more years of regular unprotected coitus. Causative factors related to - female (30 to $40 \%$ ), male (40 to $50 \%$ ), related both partner $(10 \%)$ and unexplained cause is (10\%). Factors related to female: (According to FIGO manual) are Tubal block causing 
infertility (25 to $35 \%$ ) , Uterus causes(1 to $10 \%$ ), Ovarian causes(30 to $40 \%$ )

Treatment for tubal block is Tuboplasty, Ayurveda is defined very differently Tubal blockage from modern science that the pathogenesis of It is initiated with the accumulation and vitiation of kapha \& vata Doshas.

Acharya Sushruta has considered four factors essential for conception:

Ritu, Kshetra (genital organs especially uterus, fallopian tube), Ambu (nourshing substances) \& Beeja (ovum and sperms)

Due to vitiation of kapha vata Doshas tubal block occurred. Any pathology in above factors can cause infertility In present case study tubal block treated with Kshartailauttarbasti followed by Phalaghritauttarbasti. Hence, this study was carried out as a very preliminary but sincere step on the path of infertility management through Ayurveda

AIMS: Evaluation of the efficacy of Kshartail uttarbati followed by Phalaghrita uttarbasti locally

\section{LITERATURE:}

Artavavahi dhamanis (fallopian tubes), These are two in number having roots in the Garbhashaya and injuries to Artavavahi Dhamnis, which causes Vandhyatva (infertility).The fallopian tube being a part of the uterus (Garbhashaya) is automatically accepted as the place of fertilization. According to some authors, description of Gavinis in the Atharvaveda it's also compared with the fallopian tubes. For tubal block, we can gives uttarbastti in infertility due to tubal block ${ }^{3}$.

\section{MATERIAL AND METHODS:}

- Study carried out on one patient, which was selected according to selection criteria after clinical examination and investigation.

- Kshartaila and Phalaghrita is taken from GMP certified company.

\section{Criteria of inclusion:}

- Age between 20-35yrs

- Tubal block confirmed by HSG

- Unilateral/bilateral tubal block

\section{Criteria of exclusion:}

- Age below 20 and above 35yrs

- Genital tuberculosis

- PID

- Endometriosis

- Systemic tuberculosis

- Genital malignancy

- Hydrosalphinx

- Cervical erosion, cervicitis, vulvovaginitis

- Suffering with any severe illness

- Per tubal adhesions

\section{Case report:}

$28 \mathrm{yr}$ old women wanted to investigate for primary infertility. She was housewife, married 10yrs back, staying with her husband.

- $\mathrm{C} / \mathrm{O}-$ Pain during menstruation $-1 \mathrm{yr}$

- Menstrual history - 23/28days)regular 
- In her systemic examination, all parameters are normal

- General condition was good

- P/A examination-NAD

- P/S-cervix-no erosion, discharge

- P/V-Cervix-normal

- Uterus-slight bulky, fx-tenderness both fx

- Investigation Reports are within normal limit.

HSG report shows that-mucosal irregularity noted in contrast pacified uterine cavity, with chronic inflammation. Right tube corneal block with left tube terminal block. Follicular study report was normal.

Her husbands-semen analysis report within normal limit. She was taken modern treatment for primary infertility from three years regularly. But, she was not conceives .

she under goes IUI for three cycle, treatment was fail. Lastly tuboplasty was advise by modern gynecologist, so she came for Ayurvedic treatment only.

\section{Chikitsa :}

Kshartail Uttarbasti $3 \mathrm{ml}$ is given on $5^{\text {th }}$ day, $6^{\text {Th }}$ day $\& \& 7^{\text {th }}$ day of menstrual cycle , followed by phalaghru Uttarbasti $3 \mathrm{ml}$ for $8^{\text {th }}$ day, $9^{\text {th }}$ day, $10^{\text {th }}$ day, $11^{\text {th }}$ day, $12^{\text {th }}$ day .This treatment was given for three month.

\section{After Three Months:}

- No Pain during menstruation

- Systemic examination - All parameters are normal limits

- P/A-soft

- $\mathrm{P} / \mathrm{S}$ - within normal limit

- Cervix-no erosion, discharge

3 | Nov- 2020 | Vol. 08 $8^{\text {th }} \mid$ Issue: $6^{\text {th }}$
- $\mathrm{P} / \mathrm{V}$--Cervix-normal

- Fx-no tenderness Uterus - normal size

- HSG Report - Rt. Fallopian tube cornual mild block, And at Lt. Fallopian tube within normal limit.

\section{DISCUSSION:}

According to Ayurveda, Avarodha (BLOCK) any strotasa of body is cause by Vata and kapha, in fallopian tubes block, Apanavayu vitiation is the reason. Uttarbasti is ideal local therapy is to be adopted in tubal block. Kshartail is very good lekhan property, also taila is having the property to reach minute channels in body.

Phalaghruta is best for all yonirogas, also to reduces dhaha which is due to Kshar tail. Hence, it can be concluded that the local treatment (Sthanicchikitsa) is giving encouraging results in case of tubal block. Uttarbasti with Kshar tail \& Phalghruta works very effective to relives tubal block in a short periods of three months time.

The most probable complications of Uttar Basti, are genitourinary infections and oil embolism. Good surveillance was carried out to diagnose any such complications as early as possible. However, the most encouraging point was that no feature of infection or oil embolism was observed during or after the procedure and even in the follow-up period. Proper antiseptic care, before and after the procedure does not allow any infection to grow. Uttar Basti carried out gently with a steady pace and confident skill prevents any complication like oil embolism, and severe abdominal pain. 


\section{Result:-}

Kshartail uttar basti followed by Phalagruta uttarbasti having very good result in fallopian tubal block

However to confirm this observation further large scale evaluation with more parameters is required.

\section{References:-}

1. Charak Samhita with Savimarsh Vidyotini commentary -Kasinatha Sashtri, Gorakha Natha ChaturwediChaukhambha Bharati Academy-9th, 2001.

2. Sushruta Samhita with Ayurtatva Sandeepika Commentary- Kaviraja Ambikadutta Shastri- Chaukhambha Sanskrit Sansthan-17th, 2003.

3. Astanga Sangraha with Hindi commentary-Kaviraj Atridev GuptaKrishana das Academy, VaranasiReprint 1993, Vol .A.S.du28/62, 70, 71

4. Ayurvediya PanchKarma VidnyanaVd. Haridas Sridhar Kasture-
Baidyanath Ayurved Bhavan-7th , 2006.

5. Dravyaguna Vidnyana Vol. 2- Prof. Priyavat Sharma- Chaukhamba Bharati Academy, Varanasi-2000 Reprint.

6. Ayurvediya Prasuti-Tantra Evum Stree-roga - Part I \& II- Prof. Premvati Tewari- Chaukhambha Orientalia, Varanasi-2 $2^{\text {nd }} 2000$.

7. Jeffcoat's Principles of Gynaecology- Pratapkumar and Narendra Malhotra- Jaypee brothers Medical Publishers New Delhi$7^{\text {th }} 2008$.

8. Text book of gynaecology- D.C. Dutta- New Central Book Agency(P)Ltd., Calcutta- $6^{\text {th }} 2004$.

9. www.ijapc.com Int J AyuPharm Chem research article Viabhav $\mathrm{K}$ Bhagdage, and Milind B NikumbheIssn 2350-0204

\section{Cite this article:}

"Effect of uttarbasti locally in fallopian tubal block - a case study."

Mule Kavita C., Deshmukh Jayashri S.

Ayurlog: National Journal of Research in Ayurved Science- 2020; (8) (6):01- 04 